\title{
Fishing ground and tuna productivity by tuna longline based on Benoa Bay, Bali, Indonesia
}

\author{
MOHAMMAD IMRON, MUHAMMAD IRSYAD TAWAQAL, ROZA YUSFIANDAYANI \\ Department of Fisheries Resources Utilization, Faculty of Fisheries and Marine Sciences, Institut Pertanian Bogor. Jl. Agathis, IPB University Campus \\ Darmaga, Bogor 16680, West Java, Indonesia. Tel.: +62-251-8622935, Fax.: +62-251-8421732, `email: mohammadim@apps.ipb.ac.id
}

Manuscript received: 25 November 2020. Revision accepted: 23 January 2021.

\begin{abstract}
Imron M, Tawaqal MI, Yusfiandayani R. 2021. Fishing ground and tuna productivity by tuna longline based on Benoa Bay, Bali, Indonesia. Biodiversitas 22: 961-968. The success of a longline fishing operation depends on several things such as the skill of the crew, bait used, fishing season, fishing operation, the total of fish caught, the price of the fish, productivity, and fishing grounds. Information about productivity and fishing ground becomes important to increase effectiveness and optimal profit. The methodology is carried out by conducting a survey to collect data to be processed and analyzed using productivity analysis based on Landing per Unit Effort (LPUE) and fishing activity analysis from the Vessel Monitoring System (VMS) to determine the Fishing Ground. We calculate tuna productivity from catch production (landing) per effort, meanwhile fishing ground use VMS data. Production tuna was landed at Benoa Bali from $2016-2018$ fluctuated. In 2016 production of tuna albacore took a portion of $34.60 \%$, yellowfin tuna $43.56 \%$, bigeye tuna $15.44 \%$, and southern bluefin tuna $6.26 \%$. Production of tuna albacore took a portion of $35.61 \%$, yellowfin tuna $42.64 \%$, bigeye tuna $12.49 \%$, and southern bluefin tuna $9.26 \%$ in 2017. Production albacore took a portion of $36.41 \%$, yellowfin tuna $41.56 \%$, bigeye tuna $11.79 \%$, and southern bluefin tuna $10.24 \%$ in 2018. The highest productivity of albacore was in August 2018 with LPUE value 1.0099 , yellowfin tuna was in July 2018 with LPUE value 1.2431, big eye tuna was in November 2018 with LPUE value 0.5538, and bluefin was at December 2017 with LPUE value 0.3864. The result of VMS data processing showed that tuna longline vessel based at Benoa has several locations of fishing grounds based on fishing activity for example Hindia High Seas, WPP NRI 714 (Telo gulf and Banda Sea), WPP NRI 718 (Aru Sea, Arafura Sea, and Timor Sea), ZEEI WPP NRI 718.
\end{abstract}

Keywords: Fishing ground, IUU Fishing, VMS

\section{INTRODUCTION}

Pelagic species, including both small pelagic fishes and large tunas, comprise the largest proportion of $21 \%$, or 19.6 million tons of global catches (including crustacean, mollusks, and freshwater fishes) (FAO 2016) and represents an economically important contribution to many nations (Brill and Hobday 2017). Tuna fisheries are among the most highly capitalized and valuable fisheries in the world (Campling 2012). Tuna are globally distributed species of major commercial importance and some tuna species are a major source of protein in many countries (Erauskin-Extramiana 2019). Tuna fisheries based in Benoa Port have experienced major changes since 1993 when yellowfin tuna dominated the catch $(62 \%)$, followed by big eye tuna and other types of tuna (Sadiyah and Prisantoso 2017). Based on estimated landing tuna in Benoa in 2009, yellowfin tuna was the main species caught $(57 \%)$, followed by big eye tuna $(37 \%)$ and southern bluefin tuna $(6 \%)$. This decrease in yellowfin tuna catch is in accordance with research conducted by the IOTC which states that yellowfin stock in the Indian Ocean is experiencing more capture (IOTC 2015). According to (Jatmiko et al. 2016) in general, the estimated production of yellowfin tuna landed on Benoa dropped dramatically by around 50\% from 5300 tons in 2010 to only around 2600 tons in 2014. Estimated production of bigeye tuna trends to stagnate from year to year with estimated production ranging from 2000-2500 tons annually. While the estimated production of southern bluefin tuna has increased significantly from 180 tons in 2010 to 950 tons in 2014, or has increased about 5 -fold in a period of 5 years. The occurrence of tuna production fluctuations in Benoa is estimated to be caused by IUU Fishing activities, one of that is transshipment activities. Overloading activities are strategic activities in the implementation of fishing businesses on longline tuna ships, but with the issuance of the Regulation of the Minister of Maritime Affairs and Fisheries of the Republic of Indonesia number 57/Permen$\mathrm{KP} / 2014$ concerning the Second Amendment to the Regulation of the Minister of Maritime Affairs and Fisheries Number PER.30 /MEN/2012 concerning Capture Fisheries Business in the Republic of Indonesia Fisheries Management Area as a basis for the prohibition of transshipment.

The problem of this research is the use of data from VMS and the condition of field catch data for tuna landed in Benoa Bali has not been used to determine the position of the Longline Boat Fishing Ground and its productivity. Therefore, it is necessary to conduct a study on fishing ground and tuna productivity to determine the condition of the fishing ground so that the fishing activities can get optimal catch, especially in Benoa Bali. Fishing productivity provides information to fishermen about the ability of fishing gear to obtain catches, while the fishing season pattern provides information to fishermen about the 
most appropriate time or season to determine fishing operations so that it can facilitate fishermen in the fishing process and reduce risk arrest business loss. The purpose of this study is to calculate the catch productivity (LPUE) of 4 types of tuna namely albacore tuna (Thunnus alalonga), yellowfin tuna (Thunnus albacores), bigeye tuna (Thunnus obesus), southern bluefin tuna (Thunnus macoyii) which landed catches in the Benoa port of Bali from the year 2016-2018 and determine fishing grounds based on fishing activities using VMS data. The characterization of fishermen's movement patterns at the scale of a fishing trip has been made easier by the implementation of vessel monitoring systems (VMS) (Joo et al. 2014).

\section{MATERIALS AND METHODS}

\section{Study area}

This research was conducted at the Benoa Harbor in Bali, Indonesia in August-September 2019.

\section{Data analysis}

The type of data collected in this study is quantitative data. The sources of data collected in this study are secondary data with survey method. Secondary data needed for catching tuna production data landed in Benoa Bali and logbook data for longline tuna ships based in Benoa. Data collection methods are presented in table 1 .
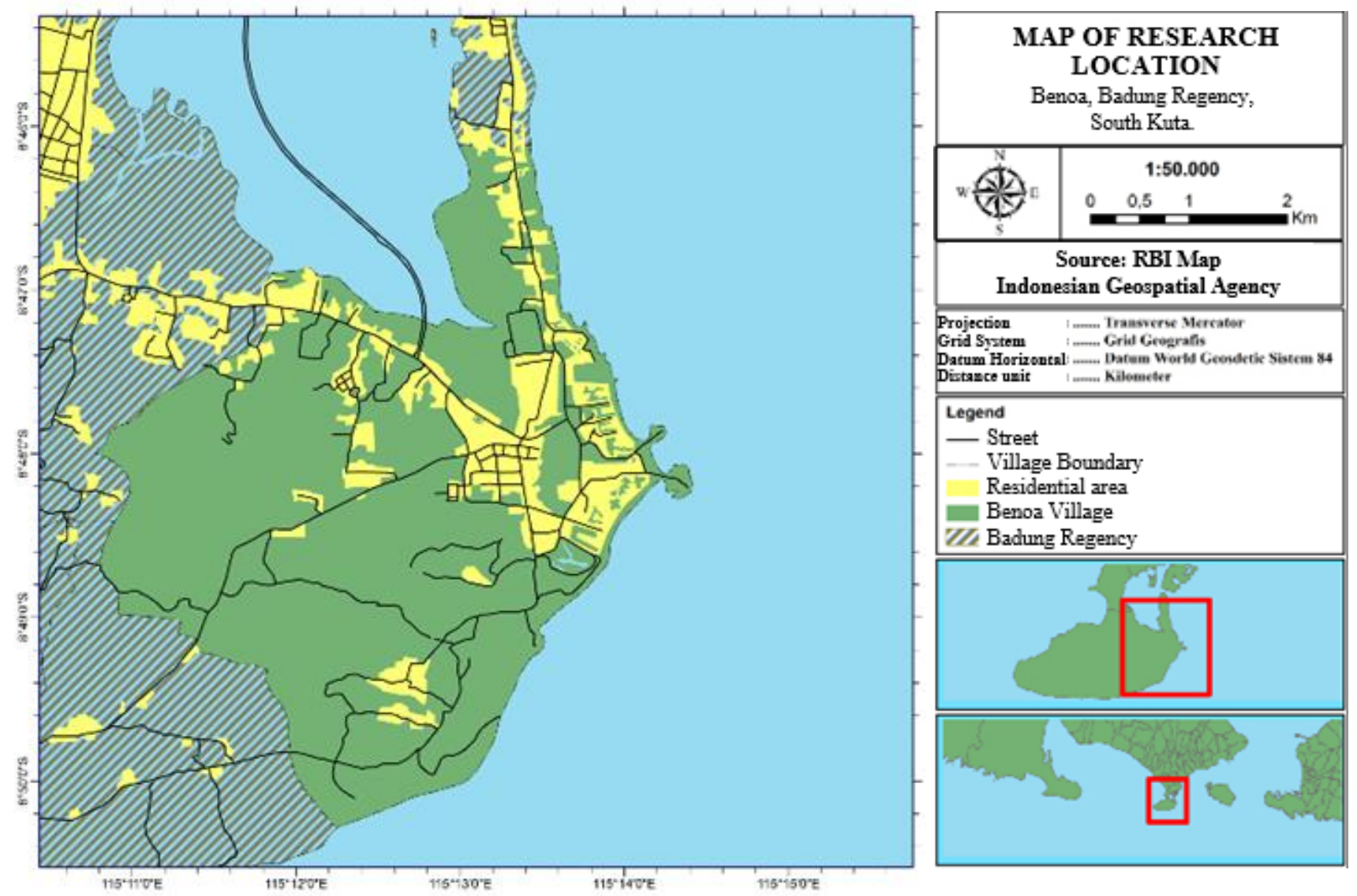

Figure 1. Location of research in Benoa Bay, Bali, Indonesia

Table 1. Method of data collection

\begin{tabular}{|c|c|c|c|c|}
\hline Method of data collection & $\begin{array}{c}\text { Data } \\
\text { collection }\end{array}$ & Data type & Data analysis & Objective \\
\hline $\begin{array}{l}\text { Determine the productivity of } \\
\text { tuna fisheries landed at Benoa } \\
\text { Harbor }\end{array}$ & Survey & $\begin{array}{l}\text { HPK data for tuna longline } \\
\text { vessels from Benoa port Bali } \\
\text { for } 3 \text { years }\end{array}$ & $\begin{array}{l}\text { Productivity analysis } \\
\text { Landing per unit effort } \\
\text { (LPUE) }\end{array}$ & $\begin{array}{l}\text { Obtaining productivity } \\
\text { from fishing longline tuna } \\
\text { landed at Benoa Harbor, } \\
\text { Bali }\end{array}$ \\
\hline $\begin{array}{l}\text { Identify the use of VMS } \\
\text { processed data to see the } \\
\text { Fishing Ground for the longline } \\
\text { tuna fishery based in Benoa }\end{array}$ & Survey & $\begin{array}{l}\text { VMS data record the direction } \\
\text { of motion of the ship and the } \\
\text { position of each vessel from } \\
\text { the sample for } 3 \text { years }\end{array}$ & $\begin{array}{l}\text { Analysis of fishing } \\
\text { activity from the Vessel } \\
\text { Monitoring System } \\
\text { data }\end{array}$ & $\begin{array}{l}\text { Obtaining fishing activity } \\
\text { and fishing ground } \\
\text { components }\end{array}$ \\
\hline
\end{tabular}


CPUE was assumed to be a proxy for fish relative abundance and we acknowledge potential issues with this assumption (e.g., Schirripa et al. 2017). Landing Per Unit Effort (LPUE) and Catch Per Unit Effort (CPUE) are used in fisheries research to indicate the abundance of resources used to conduct stock assessments when estimating the relative abundance of an exploited species. Properly applying spatial catch-per-unit-effort data as indices of fish population abundance trends also require information on changes in spatial distribution of fishing effort. CPUE represents the total value of the catch divided by the amount of effort made, while the LPUE calculates the catch that is actually captured and sold at the port by reporting. According to Metri and Perez (2014), it is stated that bycatches are usually disposed of on the ship so that the calculation of the main catches is more effective, if the bycatch is relatively stable then LPUE can provide better CPUE thinking. Landing catches can usually describe the number of specimens or the weight of the catch, and "unit effort" is represented by the value of the length of a fishing unit using its fishing gear (for example: the number of ships when soaking time per unit time). Landings data represent the landed weight of the catch, not taking into account the catch fractions that were discarded on board (Schulte et al. 2020). LPUE can be used in a variety of ways, depending on the data available and used based on different assumptions. Regression model is one of the commonly used models that aims to standardize the index and eliminate bias. In general, the calculation of LPUE values can be formulated as:

\section{LPUE $=$ LANDING $/$ TRIPS}

Where, LPUE: Landing Per Effort Unit; Landing: The total catch landed at the port by each ship per month; Trips: Number of boat trips per month.

VMS data provides information on fishing activity on a large spatial scale (Lambert et al. 2011). VMS data appears as relevant alternative to the fishing effort since it is an automated recording system. It generates high-quality information and independent of fishers' declaration. Spatial information on fishing activities remains sparse in many countries, especially in developing ones, due to a large number of fishing vessels and the high costs associated with collecting these data. Southeast Asian countries, for example, have some of the highest fishing effort densities (in boat-meters per $\mathrm{km}^{2}$ ) in the world (Stewart 2010). The introduction of Vessel Monitoring Systems (VMS) greatly increased the availability of data on the distribution of fishing activity, providing vessel-specific high-resolution data from all fishing grounds used by vessel 30 gross tonnage (GT) above at Indonesia Authority. VMS data used to show the locations and dynamics of fishing activity, usually based on density distributions of position records or reconstructed tracks (Hintzen et al. 2010; Lee et al. 2010). VMS data will be analyzed using QGIS. QGIS is open source software used to process geographic information that can collect, store, process and analyze all spatial and geographic data (Moyroud and Portet 2018). Determination of fishing grounds is done using a spatial analysis application (QGIS) by monitoring vessel movements using Vessel Monitoring System (VMS) data during 2016-2018.

\section{RESULTS AND DISCUSSION}

The composition of tuna catches by tuna longline vessels consists of albacore tuna (Thunnus alalunga), yellowfin tuna (Thunnus albacores), bigeye tuna (Thunnus obesus), southern bluefin tuna (Thunnus macoyii). The production of tuna landed in Benoa from 2016-2018 experienced fluctuations in the year. In 2016, the production of albacore tuna was 3546.816 tons (34.60\%), yellowfin tuna was 4457.161 tons $(43.56 \%)$, bigeye tuna was 1580.296 tons $(15.44 \%)$ bluefin tuna, 647.716 tons (6.26\%). In 2017 the production of albacore tuna was 2138.444 tons $(35.61 \%)$, yellowfin tuna was 2560.444 tons $(42.64 \%)$, bigeye tuna was 749.924 tons (12.49\%), southern bluefin tuna 556,328 tons (9.26\%). In 2018 albacore tuna production was 2276.945 tons (36.41\%), yellowfin tuna was 2599,224 tons $(41.56 \%)$, bigeye tuna was 737,311 tons $(11.79 \%)$, southern bluefin tuna 640.237 tons $(10.24 \%)$. The annual productivity of longline tuna and the total amount of effort fluctuate. The graph of tuna production landed at Benoa Bali in 2016-2018 is presented in Figure 2 and graph of the number of ships (> $30 \mathrm{GT}$ ) landing and capturing the results of their vessels at the Benoa port of Bali and also in Figure 3 a number of vessels recorded landing their catches at the port Bali Benoa.

Tuna production in Benoa Bali from 2016-2018 was dominated by yellowfin fish followed by albacore tuna, big eye tuna and shoutern bluefin tuna, but seen in figure 2 the production of all four types of tuna decreased from 2016 to 2017. One of the reasons is due to transshipment activities, although this regulation has been in force since 2014, but this regulation continues to be tightened in its implementation so that it has an impact on the decline in fish production recorded at the port. In October 2016 there was a conflict involving 401 ship units belonging to the tuna longline association. The conflict that occurred in the waters of Bali occurred because as many as 401 units of longline tuna ships chose to strike at sea (Hikmayani and Rahadian 2015). Hikmayani and Rahadian (2015) in their research mentioned that the implications of the enactment of the policy of the prohibition of transshipment also had quite an impact on the operational activities of ships in the PPSNZJ. The volume of fish catch landed at PPS Nizam Zachman Jakarta based on the type of ship in 2012-2015 tends to decrease. The cessation of cargo transfer activities has led to new conflicts, in which many capture fisheries have chosen not to go to sea. But in 2018 the producer has slightly increased production due to the discipline of ship owners in reporting catches, adding or replacing fishing operations to get better results but still landing their catches at Benoa port and also fisheries stakeholders such as the central government that allocates ships operating and based in Benoa in accordance with the potential of existing fish resources and fisheries officers who are getting better at carrying out their main tasks, especially in conducting data collection on both ship departure and arrival. Tuna 
productivity is obtained from production data and the amount of effort that is done so that it can know the trend of fish cultivation. The following is presented in Figure 4-7 regarding the productivity of the four tunas landed at Benoa Harbor from 2016-2018.

Albacore tuna productivity fluctuates every month. The highest productivity occurred in August 2018 with a LPUE value of 1.0099 with a production of 223.689 tons with a total effort of 221487. The lowest productivity occurred in June in 2016 with a production LPUE value of 0.1339 with a production of 369.555 tons with an amount of effort 2751504. In Figure 5 a trend on yellowfin tuna LPUE is presented.

The highest productivity of yellowfin tuna occurred in July 2018 with a LPUE value of 1.2431 with a production of 263.257 tons with a total effort of 211770 . The lowest productivity occurred in June in 2016 with a production LPUE value of 0.1339 with a production of 369.555 tons with the amount of effort 2751504. In Figure 6, the LPUE trend of bigeye tuna is presented.

The highest productivity of bigeye tuna occurred in November in 2018 with a LPUE value of 0.5538 with a production of 57.557 tons with a total effort of 103917 . The lowest productivity occurred in October 2016 with a production LPUE value of 0.0593 with a production of 127,110 tons with the amount of effort 2141000. In Figure 7 , the LPUE trend of southern bluefin tuna is presented.

The highest productivity of southern bluefin tuna occurred in December in 2017 with a LPUE value of 0.3864 with a production of 89.107 tons with a total effort of 230622. The lowest productivity occurred in October in 2016 with a production LPUE value of 0.01384 with a production of 7,133 tons with a total effort of 515398 . Utilization of VMS data can be used as validation and correlation between parameters of water fertility with the distribution of fishing vessels in determining potential DPI where the VMS data will get information on the number of operating vessels including vessel profile, position, speed, and direction of the ship when fishing (Mahabror et al. 2017). The result of data processing is that the longline tuna ship based in Benoa has several fishing ground locations, namely the Indian Ocean, WPP NRI 714 (Telo Bay and Banda Sea), WPP NRI 718 (Aru Sea, Arafura Sea, and eastern Timor Sea), ZEEI WPP NRI 718. Distribution of fishing activity for longline tuna vessels based in Benoa Bali from 2016-2018 is presented in Figure 8.

According to ship-tracking data obtained at the Directorate General of PSDKP KKP 2019, longline ships with active transmitters are 178 units operating at Benoa Harbor with ship sizes above $30 \mathrm{GT}$. The fishing ground includes WPP 714, WPP 718, and the Indian Ocean. Map distribution of tuna fishing ground by longline tuna is divided into 4 parts namely Q1 (January-March), Q2 (April-June), Q3 (July-September), Q4 (OctoberDecember). The density level of fishing activity is indicated by the color determined by using interpolation between speed data and the distance between the ship's position points obtained from VMS data, the higher the heatmap value, the distance between the ship's position points are very close together and the amount many ships, while the lower the heatmap value, the distance between the points produced are not near and the ship operates only 1 ship. As an example, the red heatmap value (highest value) shows a high level of activity density with the distance between the points of position very close together and the number of ships operating in the same area can be more than 4 vessels it can be an indication of potential fishing grounds (circled area). Map of the distribution of tuna fishing activity areas by longline tuna vessels shows that the pattern is shown by fishing activities from 20162018 there was no significant change, namely the location of fishing activities spread from $8^{\circ}-36^{\circ}$ Southern Latitude and $88^{\circ}-116^{\circ}$ East Longitude and also there are several vessels conduct fishing operations in WPP 718 with coordinates at around $6^{\circ}-10^{\circ}$ Southern latitude and $122^{\circ}$ $132^{\circ}$ East Longitude. According to Wujdi et al. (2015), fishing grounds for yellowfin tuna caught by longline tuna in Indonesia are spread from $0^{\circ}-34^{\circ}$ Southern Latitude and $76^{\circ}-134^{\circ}$ East Longitude. In 2018 as many as $11 \%$ (2 ships) which became the sample to replace their fishing grounds to the WPP 718 area indicated that the ship wanted to find a DPI that was still potential and had not been used optimally.

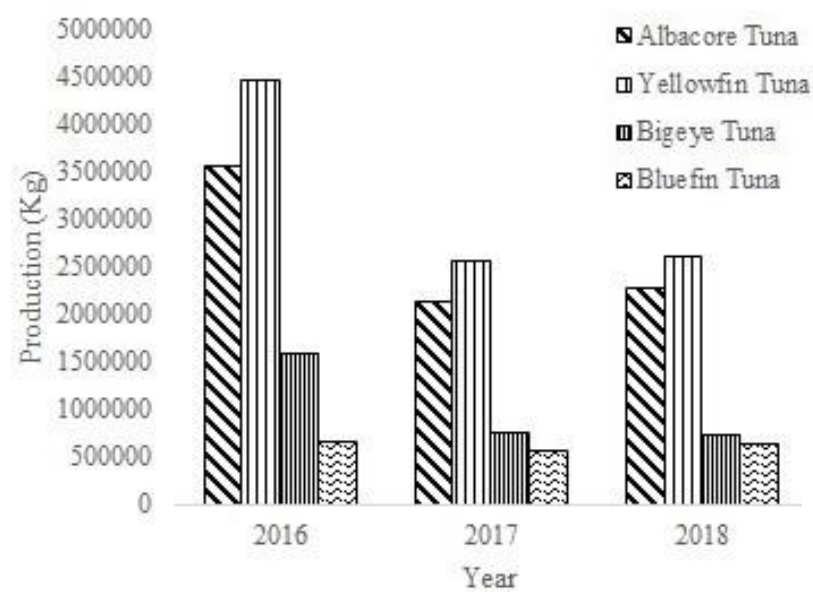

Figure 2. Tuna production landed at Benoa Bali in 2016-2018

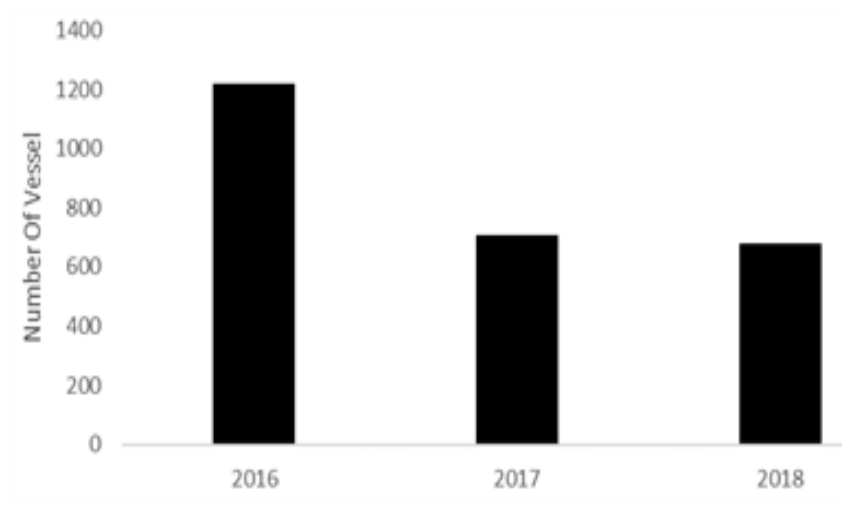

Figure 3. Number of recorded longline tuna ships landing their catches at Bali's Benoa Harbor 


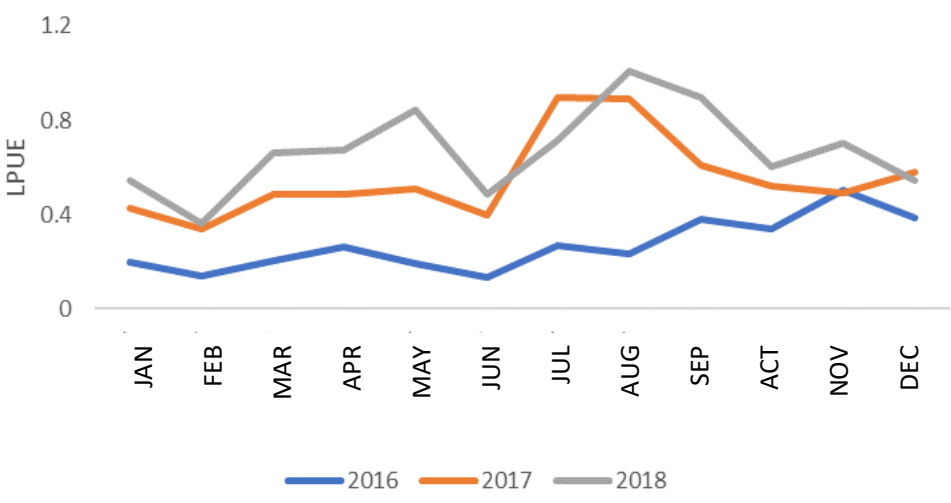

Figure 4. LPUE of albacore tuna from 2016-2018

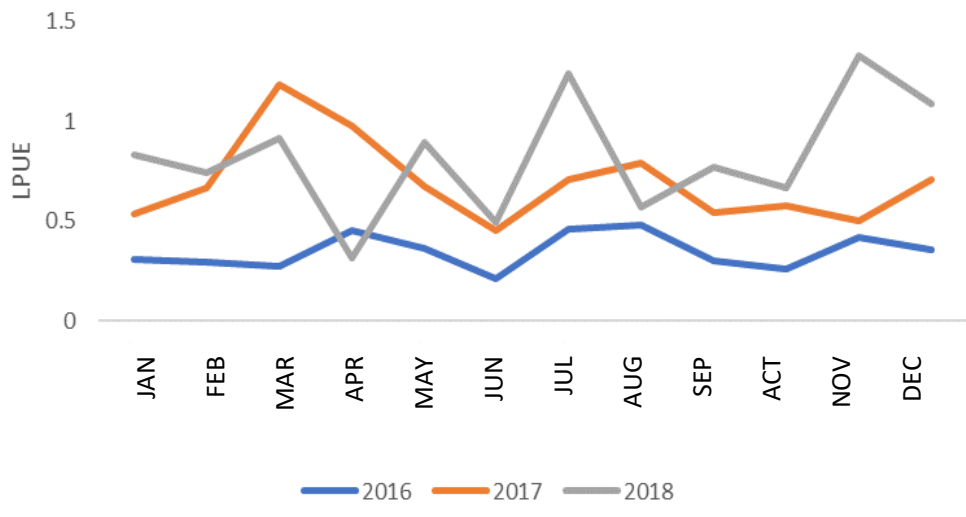

Figure 5. LPUE yellowfin tuna from 2016-2018

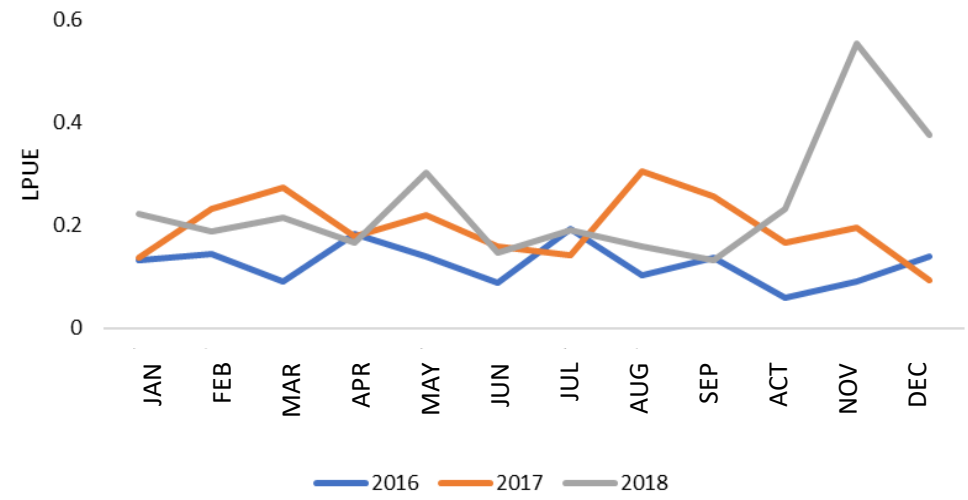

Figure 6. LPUE big eye tuna from 2016-2018

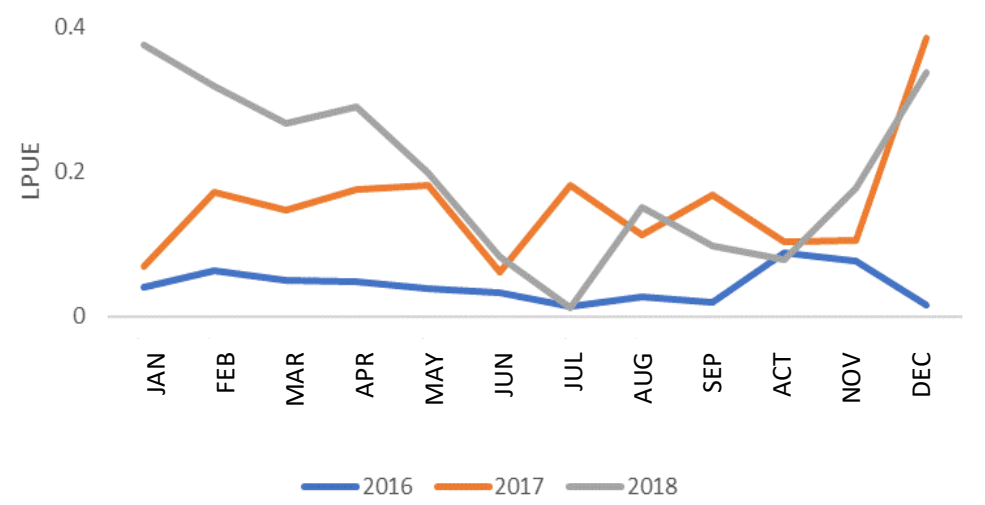

Figure 7. LPUE of southern bluefin tuna from 2016-2018 


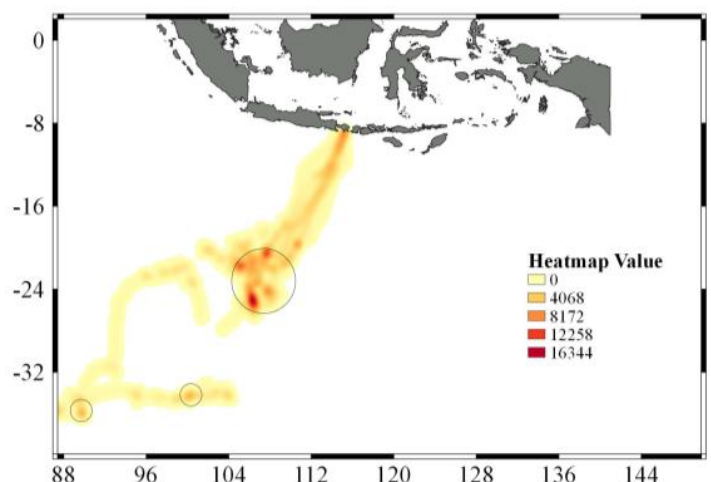

$\mathbf{A}$

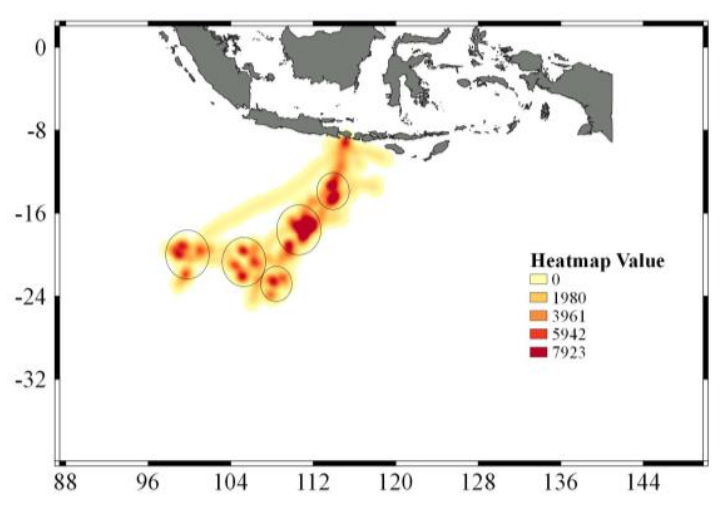

C

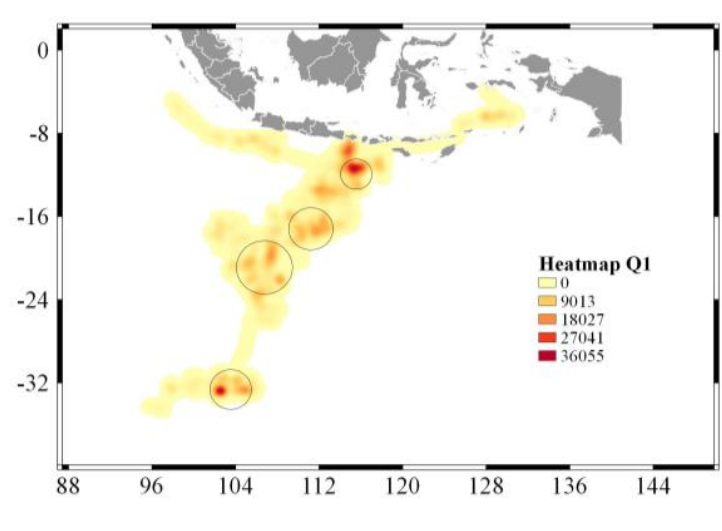

E

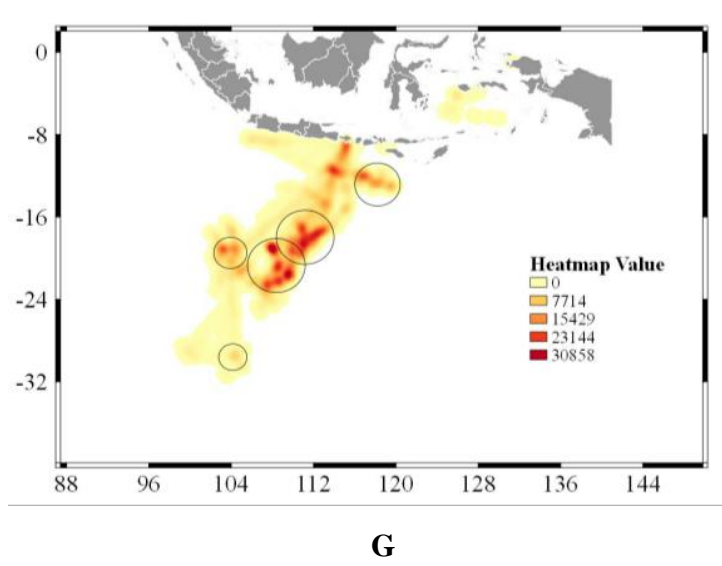

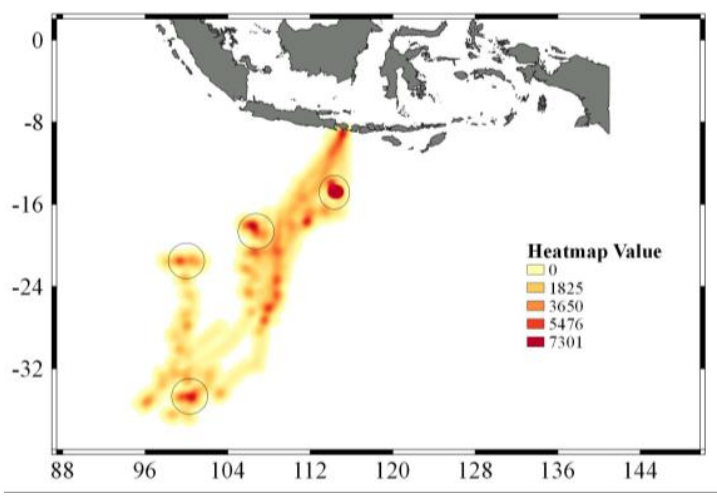

B

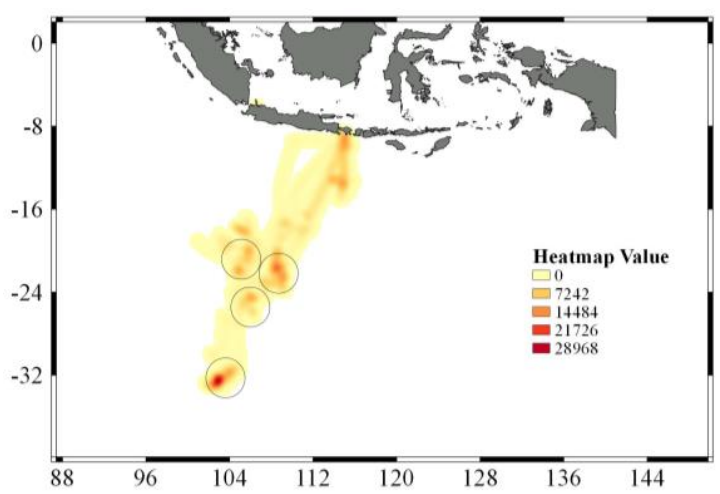

D

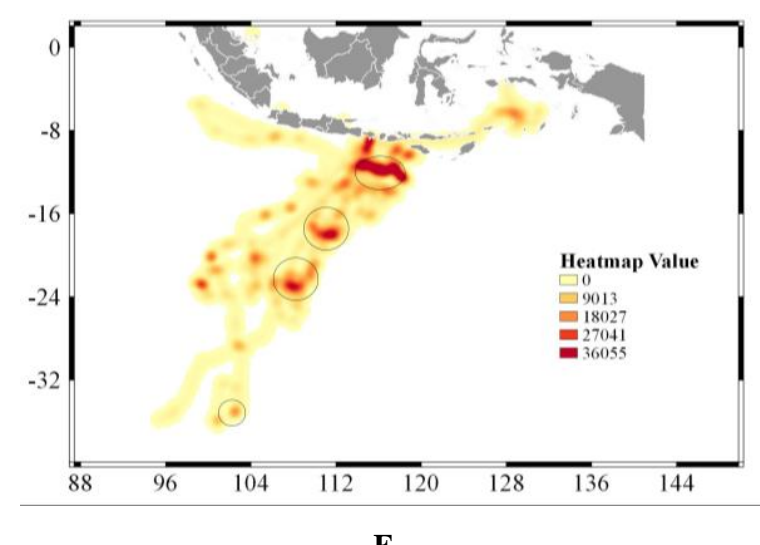

F

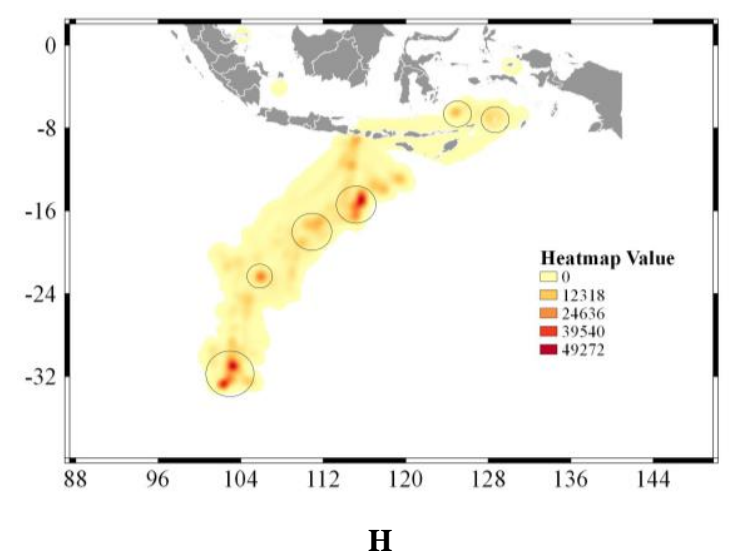



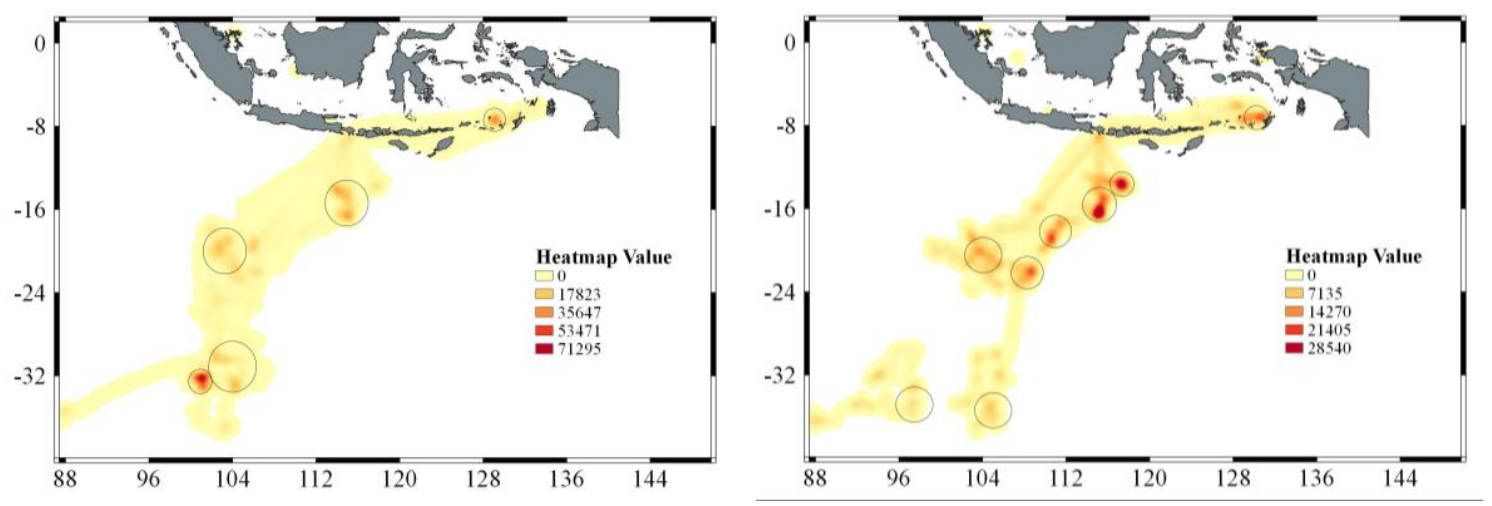

I

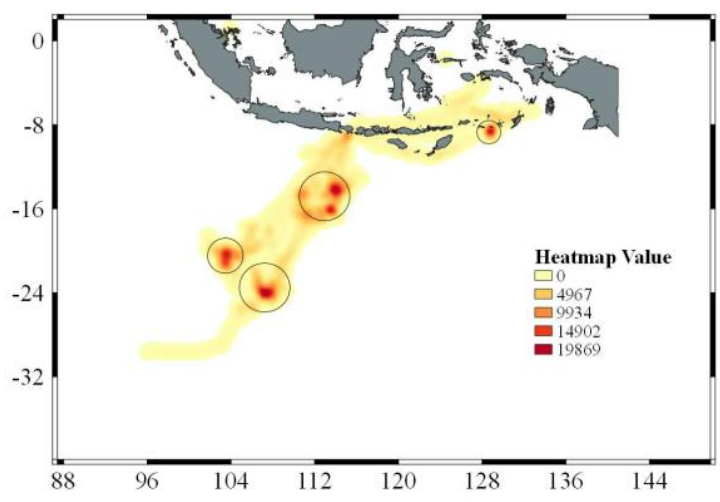

$\mathbf{K}$

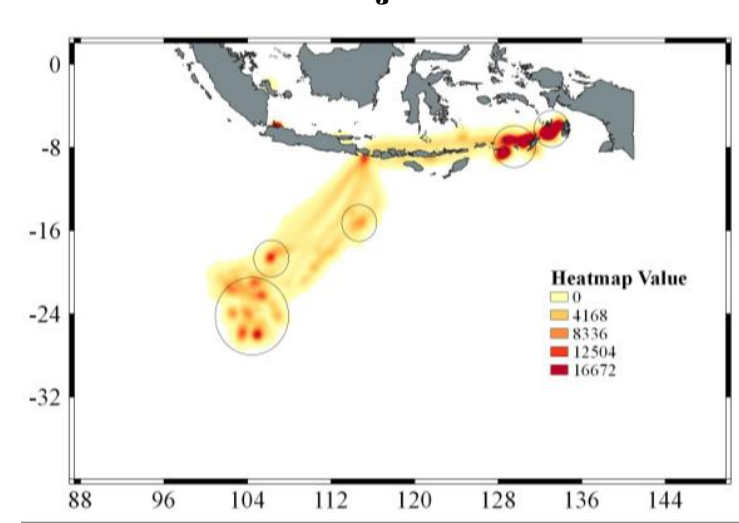

$\mathbf{L}$

Figure 8. Distribution of fishing activity for longline tuna vessels based in Benoa Bali from 2016-2018. A. January - March 2016 ; B. April - June 2016; C. July - September 2016; D. October - December 2016; E. January - March 2017; F. April - June 2017; G. July September 2017; H. October - December 2017; I. January - March 2018; J. April - June 2018; K. July - September 2018; L. October December 2018

\section{Discussion}

Catching productivity can provide information to fishermen about the ability level of fishing gear to obtain catches. If the fishing ground is known in advance, it will be more effective and efficient to increase fishing productivity. Fishermen will find it easier in the fishing process and can reduce the risk of loss from fishing efforts. An increase in fishing business and production in the long term can cause a decrease in fish biomass and fishermen's income. Information also needed in hand-line fishing is about the fishing season patterns. Currently, most fishermen still rely on experience from generation to generation. In addition to determining the fishing season pattern of each type of fish, it is hoped that fishing activities will be carried out on time and under control, and fishing will be more effective and efficient by knowing the fishing ground in advance (Harjanti et al. 2012; Branenda et al. 2019).

According to Syamsuddin et al. (2016) and Miyake et al. (2010), Fishing Ground Bigeye tuna spread throughout tropical and subtropical waters, including in the East Indian Ocean is wrong and accounts for $24 \%$ of the world's supply of bigeye tuna. The East Indian Ocean has high commercial value and produces the second-largest stock of bigeye tuna in the world after the Pacific Ocean at about $60 \%$. The southern waters of Java, the eastern Indian Ocean are potential bigeye fishing grounds which in this area are dominated by longline vessels (Wujdi et al. 2015).

The factor that affects the fertility of these waters is the presence of air-sea interactions such as ENSO and IOD that occur in the southern region of Java which has an impact on the fertility of the waters which causes the waters of the South Java region to become a hotspot for bigeye tuna (Syamsuddin et al. 2016). According to IOTC 2015, currently, around $84 \%$ of bigeye tuna have been explored in the waters of the Indian Ocean. Even so, stocks of bigeye tuna in the waters are still classified as not overfishing and not subject to overfishing, such as yellowfin tuna.

Oceanographic environmental factors such as currents and temperature have a strong relationship with the presence of tuna in Indian Ocean waters. The temperature condition under the surface layer is an indicator to determine the mass transfer of water vertically or horizontally. This transfer of water mass carries nutrients. Changes in nutrient concentrations affect water fertility and will have an impact on the distribution of tuna. The depth of layur fish swimming in the Gulf of the Indian Ocean tends to be around $0-200 \mathrm{~m}$. Temperature and current conditions at certain depths affect the preference for tuna 
fish. As a visual and phototaxis predator, tuna need light to find food and its life depends on the input of light into the water.

Fishing ground of longline by fishing activities from 2016-2018 spread from $8^{\circ}-36^{\circ}$ Southern Latitude and $88^{\circ}$ $116^{\circ}$ East Longitude and also there are several vessels conduct fishing operations in WPP 718 with coordinates at around $6^{\circ}-10^{\circ}$ latitude and $122^{\circ}-132^{\circ}$ East Longitude. Recommendations: Other research is needed on the productivity of tuna landed on Benoa Bali using different fishing gear so that the productivity data of tuna landed on Benoa will be better. Future projections about how climate change scenarios are crucial to anticipate the impacts on populations of target species (Dueri et al. 2016; Lehodey et al. 2013) and study of mapping changes in fishing grounds combined with environmental data may reveal the relationship between fishing and changes in environmental parameters (Sharples et al. 2013).

\section{ACKNOWLEDGEMENTS}

The Marine and Fisheries Service Agencies of Benoa District and The Group of Fisherman for helping and giving information and data during the research.

\section{REFERENCES}

Branenda WP, Zulkarnain, Muninggar R, Purwangka F, Apriliani IM 2019. Pola musim peangkapan ikan layur (Trichiurus spp.) di perairan Teluk Palabuhanratu, Sukabumi, Jawa Barat. Jurnal Albacore 3 (3): 297-310. [Indonesian]

Brill RW, Hobday AJ. 2017. Tunas and their fisheries: safeguarding sustainability in the twenty-first century. Fish Biol Fish 27 (1649): 691-695. DOI: 10.1007/s11160-017-9500-3.

Campling L. 2012. The tuna 'Commodity Frontier': Business strategies and environment in the industrial tuna fisheries of the Western Indian Ocean. J Agrarian Change 12 (2-3): 252-278. DOI: 10.1111/j.14710366.2011.00354.x.

Dueri S, Guillotreau P, Jiménez TR, Oliveros RR, Bopp L, Maury O. 2016. Food security or economic profitability? Projecting the effects of climate and socioeconomic changes on global skipjack tuna fisheries under three management strategies. Glob Environ Change 41: 1-12. DOI: 10.1016/j.gloenvcha.2016.08.003.

Erauskin-Extramiana M, Arrizabalaga H, Hobday AJ, Cabré A, Ibaibarriaga L, Arregui I, Murua H, Chust G. 2019. Large-scale distribution of tuna species in a warming ocean. Glob Change Biol 25 (6): 2043-2060. DOI: $10.1111 / \mathrm{gcb} .14630$.

FAO. 2016. The State of World Fisheries and Aquaculture 2016. Contributing to Food Security and Nutrition for All. FAO, Rome, Italy.

Hintzen NT, Piet GJ, Brunel T. 2010. Improved estimation of trawling tracks using Hermite spline interpolation of position registration data Fish Res 101: 108-115. DOI: 10.1016/j.fishres.2009.09.014.

Joo R, Salcedo O, Gutierrez M, Fablet R, Bertrand, S. 2015. Defining fishing spatial strategies from VMS data: Insights from the world's largest monospecific fishery. Fish Res 164: 223-230. DOI: 10.1016/j.fishres.2014.12.004.
Lehodey P, Senina I, Calmettes B, Hampton J, Nicol S. 2013. Modelling the impact of climate change on Pacific skipjack tuna population and fisheries. Clim Change 119: 95-109.

Lee J, South AB. Jennings S. 2010. Developing reliable, repeatable, and accessible methods to provide high-resolution estimates of fishingeffort distributions from vessel monitoring system (VMS) data. ICES J Mar Sci 67: 1260-1271. DOI: 10.1093/icesjms/fsq010.

Stewart KR, Lewison RL, Dunn DC, Bjorkland RH, Kelez S, Halpin PN, Crowder LB. 2010. Characterizing fishing effort and spatial extent of coastal fisheries. PLoS One 5: 556. DOI: 10.1371/journal.pone.0014451.

Harjanti R, Wibowo P, Hapsari T. 2012. Analisis musim penangkapan dan tingkat pemanfaatan ikan layur (Trichiurus sp) di Perairan Palabuhanratu, Sukabumi, Jawa Barat. J Fish Resour Utilization Manag Technol 1 (1): 55-66. [Indonesian]

Hikmayani Y, Rahadian R. 2015. Effectivity of ex-foreign ships moratorium and transshipment policy on captured fisheries business performance. Jurnal Kebijakan Sosek KKP 5 (2): 101-112.

IOTC. 2015. Report of the 17th Session of the IOTC Working Party on Tropical Tunas. https://www.iotc.org/documents/report-17th-sessioniotc-working-party-tropical-tunas.

Jatmiko I, Setyadji B, Novianto D. 2016. Tuna fisheries production catched by tuna rawai based in Benoa Harbor, Bali. Jurnal Penelitian Perikanan Indonesia 22 (1): 25-32. DOI: 10.15578/jppi.22.1.2016.2532.

Lambert GI, Hiddink, JG, Hintzen NT, Hinz H, Kaiser MJ, Murray LG, Jennings S. 2011. Implications of using alternative methods of vessel monitoring system (VMS) data analysis to describe fishing activities and impacts. ICES J Mar Sci 69: 682-693. DOI: 10.1093/icesjms/fss018.

Mahabror D, Zaky AR, Hidayat JJ 2017. Spatial and Temporal Analysis of Fishing Season with Remote Sensing Data and Vessel Monitoring System in Seas. Prosiding Seminar Nasional Kelautan dan Perikanan III. Trunojoyo University, September 2017. [Indonesian]

Metri CB, Perez JAA. 2014. LPUE (landing per unit effort) analysis of the trawl fishery for the coastal shrimps Artemesia longinaris and Pleoticus muelleri of Southern Brazil. Braz J Oceanogr 62 (4): 235245. DOI: 10.1590/s1679-87592014061306204.

Miyake MP, Guillotreau P, Sun CH, Ishimura G. 2010. Recent Developments in the Tuna Industry: Stocks, Fisheries, Management, Processing, Trade and Markets. Food and Agriculture Organization of the United Nations, Rome, Italy.

Moyroud N, Portet F. 2018. Introduction to QGIS. QGIS and Generic Tools.

Sadiyah L, Prisantoso, BL. 2017. Fishing strategy of the Indonesian tuna longliners in Indian Ocean. Indonesia Fish Res J 17 (1): 29-35. DOI: 10.15578/ifrj.17.1.2011.29-35.

Schirripa MJ, Abascal F, Andrushchenko I, Diaz G, Mejuto J, Ortiz M, Walter J. 2017. A hypothesis of a redistribution of North Atlantic swordfish based on changing ocean conditions. Deep Sea Res Part II: Topical Stud Oceanogr 140: 139-150. DOI: 10.1016/j.dsr2.2016.08.002.

Schulte KF, Siegel V, Hufnagl M, Schulze T, Temming, A. 2020. Spatial and temporal distribution patterns of brown shrimp (Crangon crangon) derived from commercial logbooks, landings, and vessel monitoring data. ICES J Mar Sci 77: 1017-1032. DOI: 10.1093/icesjms/fsaa021.

Sharples J, Ellis JR, Nolan G, Scott BE. 2013. Fishing and the oceanography of a stratified shelf sea. Prog Oceanogr 117: 130-139. DOI: 10.1016/j.pocean.2013.06.014.

Syamsuddin M, Saitoh SI, Hirawake T, Syamsudin F, Zainuddin M. 2016. Interannual variation of bigeye tuna (Thunnus obesus) hotspots in the eastern Indian Ocean off Java. Intl J Remote Sens 37 (9): 2087-2100. DOI: $10.1080 / 01431161.2015 .1136451$.

Wujdi A, Sulistyaningsih RK, Rochman F. 2015. Distribution of madidihang capture results (Thunnus Albacares Bonnaterre, 1788) in the Eastern Indian Ocean. Jurnal Penelitian Perikanan Indonesia 21 (2): 79. DOI: $10.15578 /$ jppi.21.2.2015.79-86. 